\title{
Viability and Electron Microscope Studies of Phages T 3 and T7 Subjected to Freeze-drying, Freeze-thawing and Aerosolization
}

\author{
By C. S. COX, W. J. HARRIS AND J. LEE \\ Microbiological Research Establishment, Porton Down, \\ Salisbury, Wiltshire
}

(Received Iо August 1973; revised 20 October 1973)

\begin{abstract}
SUMMARY
Phages $T_{3}$ and $T_{7}$ were freeze-dried, freeze-thawed or aerosolized. Freezedrying and aerosolization caused dehydration and resulted in a loss of viability due mainly to one factor, loss of tails. However, the extent of loss of viability and tails was critically dependent upon the manner of rehydration, slow rehydration being best for the preservation of the head-tail complex and viability. Slow freezing (at about $\mathrm{I}^{\circ} \mathrm{C} / \mathrm{min}$ ), but fairly rapid thawing (at about $200{ }^{\circ} \mathrm{C} / \mathrm{min}$ ), resulted in marked loss of viability of $\mathrm{T}_{7}$ but only slight loss for $\mathrm{T}_{3}$, through causes other than loss of tails or lysis. Collection of aerosols of $\mathrm{T}_{3}$ and $\mathrm{T}_{7}$ by impinger resulted in much lower viabilities than were obtained by subsonic impaction (e.g. about Io and $80 \%$ respectively).

The results indicate that the dehydration induced by freeze-drying and aerosolization did not cause loss of viability, but that loss of viability occurred during rehydration. Dehydration of $\mathrm{T}_{3}$ and $\mathrm{T}_{7}$ did not appear to occur during slow freezing (at about $\mathrm{I}^{\circ} \mathrm{C} / \mathrm{min}$ ). Mechanisms different from those operating through shear stresses induced by freeze-drying and aerosolization caused loss of viability when $\mathrm{T}_{3}$ and $\mathrm{T}_{7}$ were slowly frozen at about ${ }_{1}{ }^{\circ} \mathrm{C} / \mathrm{min}$.
\end{abstract}

\section{INTRODUCTION}

Bacteria subjected to freeze-drying and aerosolization become sensitive to a toxic action of oxygen and it is thought that dehydration induced by these stresses increases the rate of reaction between oxygen and a component essential for bacterial multiplication (Cox \& Heckly, 1973; Cox, Baxter \& Maidment, 1973). Even in the absence of oxygen, microbial viability is markedly affected by dehydration and rehydration (see, for example, Cox, 1966a; Dewald, Browall, Schaeffer \& Messer, 1967; Anderson \& Cox, 1967). Recently it was suggested that freezing, especially when slow (e.g. I ${ }^{\circ} \mathrm{C} / \mathrm{min}$ ), causes intracellular dehydration (Asahina, 1965; Mazur, 1965; Merryman, 1966). However, Cox \& Heckly ( 1973) showed that oxygen is not toxic for frozen bacteria, so dehydration may not occur during freezing. Comparison of survival of a micro-organism insensitive to oxygen subjected to freeze-drying, freeze-thawing and aerosolization might also indicate whether dehydration and rehydration phenomena occur during all these stresses. This suggested the experiments with phages $\mathrm{T}_{3}$ and $\mathrm{T}_{7}$ presented in this paper. For these organisms shear stresses induced by dehydration and rehydration occur as a consequence of freezedrying and aerosolization but do not occur during a slow freeze (about $\mathrm{I}^{\circ} \mathrm{C} / \mathrm{min}$ ) and a fairly rapid thaw (about $200^{\circ} \mathrm{C} / \mathrm{min}$ ). Phages $\mathrm{T}_{3}$ and $\mathrm{T}_{7}$ are also similar in many other ways (Adams, I959); they are both susceptible to the dehydration-rehydration stresses (Benbough, I97I; Hatch \& Warren, 1969; Warren \& Hatch, 1969) but are not killed by oxygen at atmospheric pressure (C. S. Cox, unpublished data). 


\section{METHODS}

Growth of organisms. Phages $\mathrm{T}_{3}$ and $\mathrm{T}_{7}$ were propagated in shaken, exponential phase cultures of Escherichia coli $\mathrm{B}\left(\mathrm{I} \times \mathrm{IO}^{8} / \mathrm{ml}\right)$ in nutrient broth at $37^{\circ} \mathrm{C}$. Titres of $\mathrm{I}$ to $3 \times 10^{10}$ phage $/ \mathrm{ml}$ of lysate were obtained and the phages were concentrated to a maximum titre of $\mathrm{I} \times 1 \mathrm{I}^{12}$ plaque-forming units $/ \mathrm{ml}$ by centrifuging at $80000 \mathrm{~g}$ for $30 \mathrm{~min}$ in a Model L2 $65 \mathrm{~B}$ Centrifuge (Beckman) using a type 30 rotor head. Different batches of a given phage did not always behave similarly and where relevant these findings will be discussed.

Viable counts were made by mixing $0.5 \mathrm{ml}$ of a suitable dilution of phage suspension with $2 \mathrm{ml}$ of $0.5 \%(\mathrm{w} / \mathrm{v})$ agar in nutrient broth containing $10^{8}$ Escherichia coli $\mathrm{B} / \mathrm{ml}$ at $42{ }^{\circ} \mathrm{C}$, pouring the mixture on to $\mathrm{I} \cdot 5 \%(\mathrm{w} / \mathrm{v})$ agar in nutrient broth contained in plastic Petri dishes and incubating at $37{ }^{\circ} \mathrm{C}$ for $4 \mathrm{~h}$. After this time the plaques were counted and percentage viability calculated, in terms of the viable count of unstressed suspensions being equivalent to $100 \%$ viability.

In aerosol experiments Bacillus subtilis var. niger spores were used as a tracer (Anderson \& Cox, 1967) and percentage viabilities of the test microbes calculated as before (Cox, I $966 a)$.

In all viability assays, 5 agar plates/sample with 50 to 150 plaques or colonies/plate were counted.

Freeze-drying. Portions of the phage suspensions $(0.2 \mathrm{ml})$ were cooled to $-55^{\circ} \mathrm{C}$ at $\mathrm{I} \cdot 5$ to $2.0^{\circ} \mathrm{C} / \mathrm{min}$ in serum bottles and then freeze-dried as before (Cox \& Heckly, I973) for $4 \mathrm{~h}$. Suspensions of $\mathrm{T}_{3}$ and $\mathrm{T}_{7}$ in nutrient broth or $0.05,0.1,0.2$ and 0.4 molal sucrose in nutrient broth were studied. The rehydration procedures used were: (i) addition of $2 \mathrm{ml}$ of nutrient broth; (ii) addition of $2 \mathrm{ml}$ of 2 molal sucrose in nutrient broth; (iii) exposure of the freeze-dried powder to I00\% relative humidity (r.h.) followed by either (i) or (ii). Samples were then removed for viability assay and for examination in the electron microscope (see below).

Freeze-thawing. Samples $(0.2 \mathrm{ml})$ of the phage suspension (as for freeze-drying) were cooled to $-70^{\circ} \mathrm{C}$ (usually) at $\mathrm{I} \cdot 5$ to $2 \cdot 0^{\circ} \mathrm{C} / \mathrm{min}$. After a total time of $\mathrm{I} h$ from the start of cooling, the phage suspensions were thawed at $200{ }^{\circ} \mathrm{C} / \mathrm{min}$ by holding the serum bottles in a water bath at $42{ }^{\circ} \mathrm{C}$. Samples were then taken for viability assay and examination in the electron microscope.

Aerosol experiments. These were performed as before (Cox, I966a) using a Collison spray and a rotating drum at $40 \%$ r.h. and $25.00 \pm 0.05{ }^{\circ} \mathrm{C}$ in nitrogen $(>99.999 \%$ pure, British Oxygen Co., London). For this work aerosols were stored for only $3 \mathrm{~min}$ because most loss of viability of $\mathrm{T}_{3}$ and $\mathrm{T}_{7}$ occurs within 3 s from spraying (G. S. Cox, unpublished). Aerosol samples were collected with an impactor (May, 1945) on to Formvar-coated electron microscope grids (mounted on glass slides) held directly below the slit of the fourth stage. The impactor was operated subsonically for $3.5 \mathrm{~min}$ at a flow rate of $20 \mathrm{l} / \mathrm{min}$, following which an electron microscope grid was rapidly transferred into I ml of nutrient broth which then was shaken gently. This suspension was used for viability assay. The samples for electron microscopy were reconstituted by gently bathing one of the grids with a few drops of nutrient broth.

In accordance with the recommendation made at The First International Symposium on Aerobiology in 1963 (Brachman et al. 1964) aerosol samples were also collected using impingers (May \& Harper, 1957) containing $20 \mathrm{ml}$ of nutrient broth + antifoam (G.E.C. Silicone 60 ). Additional samples were collected after the aerosol was rehumidified by exposure to $100 \%$ r.h. using the technique of Cox $(1966 b)$. 
Table I. Relationship and derived values of percentage viability and percentage tails (see text)

\begin{tabular}{|c|c|c|c|c|c|c|}
\hline Phage & Procedure & $\begin{array}{l}\text { centage } \\
\text { viability }\end{array}$ & $\begin{array}{c}\text { centage of } \\
\text { tails }\end{array}$ & $k^{*}$ & $\begin{array}{c}\% \\
\text { viability } \\
{ }^{*}\end{array}$ & viability ${ }^{*}$ \\
\hline \multirow[t]{7}{*}{$\mathbf{T}_{3}$} & FD in $\mathrm{NB}$; recon. NB & $13 \cdot 4$ & $9 \cdot 0$ & $1 \cdot 49$ & $2 \mathrm{I} \cdot 2$ & $63 \cdot 5$ \\
\hline & FD in 0.05 molal $\mathrm{Su}$; recon. 2 molal $\mathrm{Su}$ & $47^{\circ} 0$ & $34 \cdot 1$ & $1 \cdot 38$ & $80 \cdot 4$ & $58 \cdot 7$ \\
\hline & FD in 0.05 molal $\mathrm{Su}$; rehyd; recon. NB & $49 \cdot 0$ & $32 \cdot 0$ & $1 \cdot 53$ & $75 \cdot 3$ & $65 \cdot 2$ \\
\hline & $\mathrm{FT}$ in $\mathrm{NB}$ & $100 \cdot 0$ & $45^{\circ} 0$ & $2 \cdot 22$ & $106 \cdot 0$ & $94 \cdot 5$ \\
\hline & Aerosol; recon. NB & $22 \cdot 0$ & $9 \cdot 4$ & $2 \cdot 34$ & $22 \cdot I$ & $99 \cdot 6$ \\
\hline & Aerosol; rehyd; recon. NB & $66 \cdot 0$ & $28 \cdot 0$ & $2 \cdot 36$ & $65 \cdot 8$ & $100 \cdot 4$ \\
\hline & Unstressed suspension & $100 \cdot 0$ & $42 \cdot 6$ & $2 \cdot 35$ & $100 \cdot 0$ & $100 \cdot 0$ \\
\hline \multirow{7}{*}{$\mathrm{T}_{7}$} & FD in NB; recon. NB & $1 \cdot 0$ & $2 \cdot 0$ & 0.50 & $4 \cdot 5$ & $22 \cdot 4$ \\
\hline & $\mathrm{FD}$ in 0.05 molal $\mathrm{Su}$; recon. NB & $3 \cdot 2$ & $6 \cdot 7$ & 0.48 & I 4.9 & $21 \cdot 5$ \\
\hline & FD in 0.05 molal Su; recon. 2 molal Su & $13 \cdot 2$ & $25 \cdot 5$ & 0.52 & $56 \cdot 8$ & $23 \cdot 3$ \\
\hline & $\mathrm{FT}$ in NB & $21 \cdot 6$ & $47 \cdot 6$ & 0.45 & 106.0 & $20 \cdot 2$ \\
\hline & Aerosol; recon. NB & $35 \cdot 0$ & 15.9 & $2 \cdot 20$ & $35 \cdot 5$ & $98 \cdot 7$ \\
\hline & Aerosol; rehyd; recon. NB & $35^{\circ} \cdot 0$ & $15 \cdot 3$ & $2 \cdot 28$ & $34 \cdot 2$ & $102 \cdot 8$ \\
\hline & Unstressed suspension & $100 \cdot 0$ & $44 \cdot 8$ & $2 \cdot 23$ & $100 \cdot 0$ & $100 \cdot 0$ \\
\hline
\end{tabular}

$\mathrm{FD}=$ freeze-dried $; \mathrm{FT}=$ freeze-thawed $; \mathrm{NB}=$ nutrient broth; Aerosol $=$ suspension in $\mathrm{NB}$ aerosolized at $40 \%$ r.h., $25{ }^{\circ} \mathrm{C}$, sampled by impactor; $\mathrm{Su}=$ sucrose; recon. = reconstituting fluid; rehyd. = exposure to $100 \% \mathrm{r}$.h. before reconstituting. The same batches of $\mathrm{T}_{3}$ and $\mathrm{T}_{7}$ were used throughout (see Results and Discussion).

* For definition, see Results and Discussion.

Electron microscope studies. The phage suspensions deposited on Formvar-coated electron microscope grids were drained before being inverted and gently lowered on to the surface of a $2 \%(w / v)$ aqueous solution of ammonium molybdate. The specimens were satisfactorily cleaned and stained after I min and were finally coated with carbon.

The specimens were examined in a Philips EM300 electron microscope to determine the percentage of phage having visible tails, the percentage of lysed phage and the degree of penetration of the ammonium molybdate stain.

\section{RESULTS AND DISCUSSION}

Experiments were usually performed from two to five times, but results from replicate experiments sometimes varied significantly and the average variation for the data presented below was $\pm 20 \%$ of the mean viability value and $\pm 5 \%$ of the tails value. On occasions variability was much greater than these average values and where relevant the causes will be discussed.

\section{Freeze-drying}

Freeze-drying and reconstitution caused loss of viability. The extent depended upon the phage type and on the freeze-drying suspending fluid, but the overriding factor controlling survival was the manner of reconstituting the freeze-dried powder. Viability was enhanced to a marked extent in all experiments when either 2 molal sucrose was added to the nutrient broth reconstituting fluid or vapour phase rehumidification was used. Figure $\mathrm{I}$ and 2 are for $\mathrm{T}_{3}$ freeze-dried in $0 . \mathrm{I}_{\text {molal }} \mathrm{\text {or }} 0.2$ molal sucrose in nutrient broth. Similar results were obtained with the other suspending fluids examined and with $\mathrm{T}_{7}$ (Table I). Table $\mathrm{I}$ indicates that a low viability was associated with a low percentage of tails and a high viability with a high percentage of tails. 


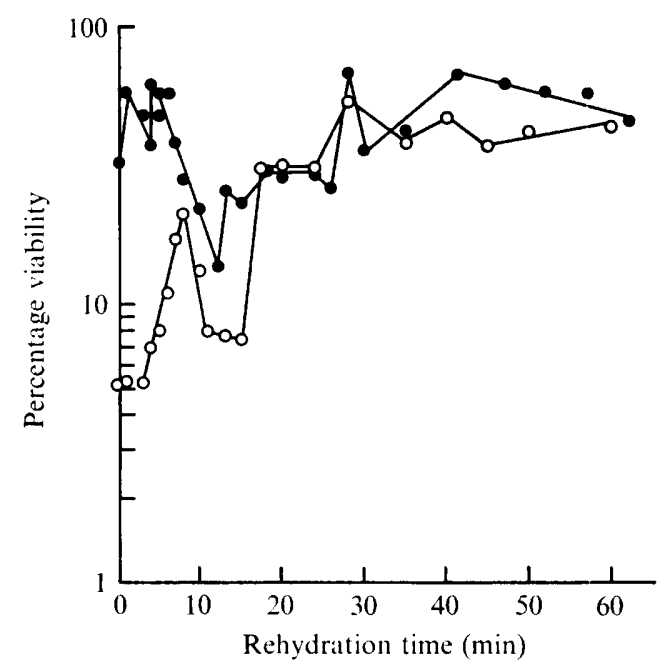

Fig. I

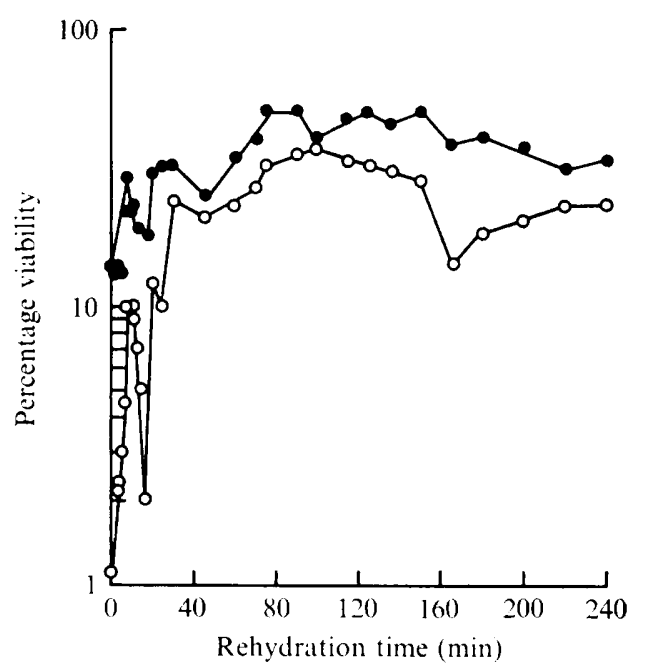

Fig. 2

Fig. I. Percentage viability of phage $\mathrm{T}_{3}$ freeze-dried in 0.1 molal sucrose in nutrient broth, as a function of time of exposure to $100 \%$ relative humidity before reconstituting with $(O)$ nutrient broth and (O) 2 molal sucrose in nutrient broth.

Fig. 2. Percentage viability of phage $T_{3}$ freeze-dried in 0.2 molal sucrose in nutrient broth. Other details as for Fig. I.

Gravimetric studies suggested that increasing the amount of sucrose in the freeze-drying suspending fluid decreased the rate of adsorption of water vapour during vapour phase rehydration. Hence, the difference in the time scale in Fig. I and 2 suggests that provided the rate of rehydration is already slow, then the extent rather than the exact rate of water vapour adsorption controls viability of reconstituted phage.

Stresses associated with freeze-drying caused little or no lysis of either $T_{3}$ or $T_{7}$, as determined by electron microscopy.

\section{Freeze-thawing}

Freezing $\mathrm{T}_{3}$ at $\mathrm{I}_{5} 5$ to $2 \cdot 0^{\circ} \mathrm{C} / \mathrm{min}$ and thawing at $200{ }^{\circ} \mathrm{C} / \mathrm{min}$ caused negligible loss of viability (Table I). However, severe losses of viability occasionally occurred and 36 freezethaw experiments were performed in an attempt to determine the cause(s) of this variation. Several possible factors, such as slight changes in the composition of the suspending fluid and in the freeze and thaw rates, were examined. None of these could be implicated as the cause(s), but since extremely complex suspending media were used (e.g. nutrient broth) the non-reproducibility is possibly due to the variable precipitation of a solid phase; such behaviour has been shown and causes variable results (Silver, I965). This explanation is supported by the finding that on cooling to $-60{ }^{\circ} \mathrm{C}$ reproducibility was good, with viability always being close to $100 \%$ even when the cooling rate was decreased to an average value of $0.77^{\circ} \mathrm{C} / \mathrm{min}$. In 36 experiments, populations of $\mathrm{T} 3$ were $100 \%$ viable on 17 occasions, approximately $60 \%$ viable on 13 occasions and approximately $10 \%$ viable on six occasions. These differences are significant because replicate viable counts were usually within $\pm 20 \%$ of the arithmetic mean.

Hatch \& Warren (1969) also had difficulty in determining the viable count of phage $\mathrm{T}_{3}$ suspensions in nutrient broth cooled to $-70^{\circ} \mathrm{C}$ and then thawed; the data of Ehrlich, Miller \& Idoine (1964) show the same phenomenon. 
With $\mathrm{T}_{7}$, consistent results were obtained on cooling to $-70^{\circ} \mathrm{C}$ followed by thawing, and the loss of viability ( $2 \mathrm{I} \cdot 6 \%$ viable) was not caused by loss of tails (Table I); no appreciable lysis was detected by electron microscopy, as for $\mathrm{T}_{3}$.

\section{Aerosolization}

Following aerosolization, storage for $3 \mathrm{~min}$ and collection by impactor, $\mathrm{T}_{3}$ and $\mathrm{T}_{7}$ gave results similar to those obtained for freeze-drying, i.e. loss of viability appeared to be related to loss of tails (Table I). With $\mathrm{T}_{3}$, slow rehydration increased percentage viability and tails, while with $\mathrm{T}_{7}$ viability and tails were the same for both reconstitution procedures (Table I). Viability of the non-rehumidified $\mathrm{T}_{3}$ sample, unlike the rehumidified sample, varied considerably with different batches of phage and viabilities ranging from about 20 to $65 \%$ were obtained with concomitant increases in percentage of tails. This variation is much greater than the more usual variation of $\pm 20 \%$ of the viability value and may indicate that the strength of the head-tail complex can vary between batches of phage $\mathrm{T}_{3}$.

Neither $T_{3}$ nor $T_{7}$ appeared to lyse (as determined by electron microscopy) as a result of the aerosolization procedures used. However, it was found that the Collison spray used to generate the aerosols could cause loss of viability of, and a corresponding loss of tails from, both $\mathrm{T}_{3}$ and $\mathrm{T}_{7}$. Collison sprays rely on a refluxing action of the spray suspensions and this, if excessive, produced the above effects. Under the conditions of the experiments ( $2 \mathrm{ml}$ of spray suspension) the spray pot contents were cycled every $2 \mathrm{~s}$; refluxing (or spray) times of up to 2 min caused negligible loss of viability or tails, but refluxing times of 4 min often caused a $50 \%$ loss in viable and tail counts. In experiments to obtain the data in Table $\mathrm{r}$, the Collison spray was operated for only $30 \mathrm{~s}$, and after completing aerosol generation the phage suspension left in the spray pot was always checked for possible loss of viability and tails.

Aerosol samples were also collected by raised impinger and viability in these samples was nearly always significantly less than that in samples collected by subsonic impactor. For example, for $\mathrm{T}_{3}$ impactor viabilities were $22.0 \%$ without rehumidification and $66 \%$ with rehumidification (Table I), while the corresponding impinger viabilities were 0.52 and $11.5 \%$, agreeing with the corresponding values of 0.1 and 10 found by Hatch \& Warren (I969); for $\mathrm{T}_{7}$ the relevant viabilities were 35.0 and $35.0 \%$ (Table $\mathrm{I}$ ), and $0.8 \mathrm{I}$ and $35.4 \%$, respectively. Hence, the action of the impinger could cause significant damage to both $\mathrm{T}_{3}$ and $\mathrm{T}_{7}$, probably through shear of tails from phage heads. Phenomena of this nature were considered previously (Anderson \& Cox, 1967) and Rechsteiner (I970) showed that the action of sonic impingers caused severe loss of viability of respiratory syncytial virus.

These findings suggest that, if rehumidification were coupled with a very gentle sampling technique, viability of $\mathrm{T}_{3}$ and $\mathrm{T}_{7}$ would probably be unaffected both by aerosolization into, and collection from, rotating drums, and also by the simulated aerosol techniques described by Cox (1965), Silver (1965) and Anderson \& Cox (I967).

\section{Stain penetration}

No exact correlation was found between viability and degree of penetration of the ammonium molybdate stain. With $\mathrm{T}_{3}$ and $\mathrm{T}_{7}$ stressed by freeze-drying, penetration increased as viability decreased, although freezing and thawing of $\mathrm{T}_{3}$ and $\mathrm{T}_{7}$ did not cause penetration. However, aerosolized $\mathrm{T}_{3}$ and $\mathrm{T}_{7}$ were completely penetrated irrespective of viability. 


\section{General discussion}

If a stress is applied to a portion of the stock suspension, such that the only action of the stress is to separate tails from the phage head-tail complexes, then the relationship percentage viability/percentage of tails ( $k$ ') obtained with the stressed suspension will be the same as that for the unstressed suspension of phage. However, if the applied stress causes loss of viability by other mechanisms the value of $k$ will differ from that for the unstressed suspension. Hence, calculation of the value of $k$ for differently stressed samples allows the determination of loss of viability caused by loss of tails and that caused by other mechanisms. For this analysis, ' $\%$ viability $_{1}$ ' will be used to represent the former case and ' $\%$ viability' ${ }_{2}$ the latter, while 'viability ${ }_{1}$ ' multiplied by 'viability ${ }_{2}$ ' (corresponding to the observed percentage viability) will be the resultant of the two phenomena.

Values of $k$ and percentage viability obtained as above are given in Table I. Percentage viability $_{1}$ for $\mathrm{T}_{3}$ shows that controlled rehydration prevented significant loss of tails and correspondingly increased viability. Percentage viability ${ }_{2}$ indicates that a fairly constant proportion of $\mathrm{T}_{3}$ was inactivated during the processes involved in freeze-drying and that this inactivation was independent of the suspending fluid and the rehydration procedures. The cause of this viability loss is not known but could have been entirely due to freezing. From the results of freeze-thawing experiments this seems possible, but it could also have been because of dehydration only. For aerosolized $\mathrm{T}_{3}, \%$ viability ${ }_{2}$ was close to $100 \%$ (Table I) and therefore dehydration resulting from exposure to $40 \% \mathrm{r}$.h. did not cause viability loss other than through loss of tails. However, the degree of dehydration produced by freeze-drying would have been much greater than that by aerosolization, because $T_{3}$ during freeze-drying would have been exposed to almost zero r.h. Hence, the reason why $\%$ viability $_{2}$ for freeze-dried $\mathrm{T}_{3}$ was less than $\mathrm{I} 00 \%$ (Table $\mathrm{I}$ ) is not completely understood.

Percentage viability ${ }_{1}$ values for $T_{7}$ indicate similar behaviour to that for $T_{3}$, that is, freeze-drying and aerosolization result in loss of viability and tails (Table I). However, $\%$ viability $_{2}$ is significantly less than $100 \%$ for freeze-dried and freeze-thawed $\mathrm{T}_{7}$ (Table 1 ), unlike aerosolized $\mathrm{T}_{7}$ (Table $\mathrm{I}$ ). Hence, a similar stress must have been imposed during freeze-drying and freeze-thawing of $\mathrm{T} 7$, but not during its aerosolization. The most likely explanation of these results is that the single action of freezing $T_{7}\left(1 \cdot 5\right.$ to $\left.2.0^{\circ} \mathrm{C} / \mathrm{min}\right)$ caused loss of viability independently of loss of tails, or lysis, as determined by electron microscopy.

Following aerosolization and collection by impactor, $\mathrm{T}_{3}$ and $\mathrm{T}_{7}$ both lost viability (Table I), but this viability loss was caused solely by loss of tails since the value of $k$ is close to that for an unstressed phage suspension and $\%$ viability $_{2}$ is approximately $100 \%$ (Table 1 ). $\mathrm{T}_{3}$ and $\mathrm{T}_{7}$ differed slightly in that $\%$ viability $_{1}$ of $\mathrm{T}_{3}$, unlike that for $\mathrm{T}_{7}$, was sensitive to rehydration. Since no death mechanism other than tail loss was detected, these results are entirely consistent with those of E. J. Dubovi (personal communication) obtained with $\phi \mathrm{X}_{\mathrm{I}} 74$. Dubovi found that the viability of $\phi \mathrm{X}_{\mathrm{I}} \mathrm{74}$ collected from aerosols at low r.h. decreased by a factor of $10^{4}$, while DNA extracted from such non-viable phage was as infectious for spheroplasts as that extracted from unstressed $\phi \mathrm{X}_{1}$ 74. Hence, as a consequence of aerosolization, storage and collection $\phi \mathrm{X}_{174}$, like $\mathrm{T}_{3}$ and $\mathrm{T}_{7}$, is unable to infect its host bacterium. Similarly, the results of Trouwborst \& de Jong (1972) can be accounted for. They labelled the DNA in phage $\mathrm{T}_{\mathrm{I}}$ with ${ }^{32} \mathrm{P}$. After aerosolization and rapid rehydration, phage viability exactly paralleled the degree of adsorption of ${ }^{32} \mathbf{P}$ to the host bacterium Escherichia coli $\mathrm{B}$. Analysis of the collected $\mathrm{T}$ I on a $\mathrm{CsCl}$ gradient showed that the density 
of moieties corresponding to maximum radioactivity was $\mathrm{I} \cdot 67 \mathrm{~g} / \mathrm{cm}^{3}$, while that for complete phage was I.52. Trouwborst \& de Jong (1972) suggested that these results were because of release of ${ }^{32} \mathrm{P}$ from the phage head, i.e. lysis. However, according to The Handbook of Biochemistry (1968) the density of TI DNA is $\mathrm{I} \cdot 705 \mathrm{~g} / \mathrm{cm}^{3}$, which is considerably greater than the value of ${ }_{\mathrm{I}} \cdot 67$ for the moieties containing ${ }^{32} \mathrm{P}$. Therefore, Trouwborst \& de Jong (1972) may not have found free TI DNA, but DNA contained in TI phages without tails, so that loss of tails could also account for their results. Electron microscope studies similar to those performed here should either confirm or eliminate this possibility.

The finding that following dehydration $\mathrm{T}_{7}$ can lose tails on rapid rehydration provides an explanation for the results of Cox \& Baldwin (1964; I966) which indicate that the aerosol survival of $\mathrm{T}_{7}$, when adsorbed on to Escherichia coli $\mathrm{B}$, increased as the pre-aerosolization time of contact between phage and $E$. coli was increased. With increasing preaerosolization contact time, the percentage of host bacteria containing T7 DNA would have increased up to I00. Once the T7 DNA was transferred from the phage head via the tail into the host bacterium, separation of phage heads from the head-tail-host complexes would not influence the subsequent development of $\mathrm{T}_{7}$ progeny. Such infected bacteria would have scored as viable phage and therefore $\mathrm{T}_{7}$ viability would appear to increase with increased pre-aerosolization contact time until $\mathrm{T}_{7}$ viability reached $100 \%$.

The observation that, following dehydration, loss of tails from $\mathrm{T}_{3}$ and $\mathrm{T}_{7}$ occurs only during rehydration suggests that water molecules might be involved in the attachment of phage tails to phage heads. On dehydration such water molecules would be removed and result in head-tail complexes with reduced physical strength. The physical integrity of such complexes would therefore become extremely susceptible to the shear forces which occur on the addition of bulk water and to those operating during aerosol sampling by impinger. Both situations resulted in low viability with concomitant loss of tails (Table I). Furthermore, the phenomenon of tail loss might be expected to increase with increasing dehydration and in fact Warren \& Hatch (1969) found that $T_{3}$ viability decreased as r.h. decreased.

Results of Warren \& Hatch (I969), in conjunction with our own, also indicate that the number of water molecules required for maximum shear resistance of the head-tail complexes could be quite large. Even at $95 \%$ r.h. T3 loses appreciable viability, yet many biological materials exposed to this r.h. lose only small amounts of water (Bull, I95I; Northcote, I953; Falk, Hartman \& Lord, I962; I963; Bateman, Stevens, Mercer \& Carstensen, 1962). The situation for $\mathrm{T}_{3}$ also applies to $\mathrm{T}_{7}$, because significant viability loss occurs above $80 \%$ r.h. and becomes more extensive as the r.h. is lowered (Benbough, 197I). Extension of studies to include the effects of r.h., together with measurements of water sorption isotherms, now seems to be required.

Loss of viability and tails also can be caused by shear forces other than those considered in our work because Williams \& Fraser (I953) showed that phages TI to T7 subjected to high gravitational forces lost viability and tails, as we confirmed in the case of T7. Williams \& Fraser (I953) also indicate that $\mathrm{T}_{3}$ and $\mathrm{T}_{7}$, and perhaps other phages, lost tails during the air-drying procedures they used in the preparation of their phage samples for electron microscopy. Hence, loss of tails from $T$ phages appears to be a general result of shear stress. Therefore it is perhaps not surprising that $\mathrm{T}_{3}$ and $\mathrm{T}_{7}$ did not lose tails on freezing and thawing, since shear stresses probably were not severe in our freeze-thawing experiments. Extremely rapid thawing rates (well in excess of $200{ }^{\circ} \mathrm{C} / \mathrm{min}$ ) applied to frozen suspensions of $\mathrm{T}_{3}$ and $\mathrm{T}_{7}$ may cause shear stresses sufficiently great to result in loss of viability through loss of tails from potentially dehydrated phages $\mathrm{T}_{3}$ and $\mathrm{T}_{7}$. 


\section{REFERENCES}

Adams, M. H. (1959). Bacteriophages. New York and London: Interscience Publishers.

ANDerson, J. D. \& Cox, C. S. (1967). Microbial Survival. Symposia of the Society for General Microbiology 17, 204-226.

Asahina, E. (1965). Freezing process and injury in isolated animal cells. Federation Proceedings 24, S183-I87.

Bateman, J. B., Stevens, C. L., Mercer, W. B. \& Carstensen, E. L. (I962). Relative humidity and the killing of bacteria: the variation of cellular water content with external relative humidity or osmolality. Journal of General Microbiology 29, 207-219.

BenBough, J. E. (1971). Some factors affecting the survival of airborne viruses. Journal of General Virology Iо, 209-220.

Brachman, P. S., Ehrlich, R., Eichenwald, H. F., Gabelli, V. J., Kethley, T. W., Madin, S. H. Maltman, J. R., Middlebrook, G., Morton, J. D., Silver, I. H. \& Wolfe, E. K. (1964). Standard sampler for assay of airborne micro-organisms. Science, New York 144, 1295.

BulL, H. B. (1951). Physical Biochemistry. London: Chapman and Hall.

Cox, C.S. (1965). Protecting agents and their mode of action. First International Symposium on Aerobiology, pp. 345-368. Oakland, U.S.A.: Naval Biomedical Research Laboratory.

Cox, C. S. (1966a). The survival of Escherichia coli atomized into air and into nitrogen from distilled water and from solutions of protecting agents, as a function of relative humidity. Journal of General Microbiology 43, 383-399.

Cox, C.S. $(1966 b)$. The survival of Escherichia coli in nitrogen atmospheres under changing conditions of relative humidity. Journal of General Microbiology 45, 283-288.

Cox, C. S. \& BALDwIN, F. (1964). A method for investigating the cause of death of airborne bacteria. Nature, London 202, I 135.

Cox, C. S. \& Baldwin, F. (1966). The use of phage to study causes of loss of viability of Escherichia coli in aerosols. Journal of General Microbiology 44, 1 5-22.

Cox, C. S., BAXTER, J. \& MAIDMEnT, B. J. (1973). A mathematical expression for oxygen-induced death in dehydrated bacteria. Journal of General Microbiology 75, 179-185.

Cox, C. S. \& HeCKLY, R. J. (1973). Effects of oxygen upon freeze-dried and freeze-thawed bacteria: viability and free radical studies. Canadian Journal of Microbiology 19, 189-194.

Dewald, R. R., Browall, K. W., Schaeffer, L. M. \& Messer, A. (1967). Effect of water vapour on lyophilized Serratia marcescens and Escherichia coli. Applied Microbiology 15, $1299-1302$.

EHRLICH, R., MilleR, S. \& IDOINE, L. S. (1964). Effects of environmental factors on the survival of airborne T3 coliphage. Applied Microbiology 12, 479-482.

Falk, M., Hartman, K. A., Jun. \& LoRD, R. C. (I962). Hydration of deoxyribonucleic acid. I. A gravimetric study. Journal of the American Chemical Society 84, 3843-3846.

Falk, M., Hartman, K. A., Jun. \& LoRd, R. C. (I963). Hydration of deoxyribonucleic acid. II. An infrared study. Journal of the American Chemical Society 85, 387-39I.

Hatch, M. T. \& WARren, J. C. (I969). Enhanced recovery of airborne T3 coliphage and Pasteurella pestis bacteriophage by means of a presampling humidification technique. Applied Microbiology 17, 685689.

MAY, K. R. (I945). The cascade impactor: an instrument for sampling coarse aerosols. Journal of Scientific Instruments 22, I87-195.

MAY, K. R. \& HARPER, G. J. (1957). The efficiency of various liquid impinger samplers in bacterial aerosols. British Journal of Industrial Medicine 14, 287-297.

Mazur, P. (1965). Causes of injury in frozen and thawed celis. Federation Proceedings 24, Si75-182.

MerRyman, H. T. (1966). The interpretation of freezing rates in biological materials. Cryobiology 2, I65-I70.

NoRTHCOTE, D. H. (1953). The sorption of water vapour by yeast cell wall and other polysaccharides. Biochimica et biophysica acta 11, 471-479.

ReChSTEINER, J. (1970). The recovery of airborne respiratory syncytial virus. In Proceedings of the 3 rd International Symposium on Aerobiology. London: Academic Press.

Silver, I. H. (1965). Viability of microorganisms using a suspended droplet technique. First International Symposium on Aerobiology, pp. 319-333.

The Handbook of Brochemistry (1968), Section H. Edited by H. A. Sober. Cleveland, Ohio, U.S.A.: Chemical Rubber Co. 
Trouwborst, T. \& DE JoNG, J. C. (1972). Mechanism of inactivation of the bacteriophage TI in aerosols. Applied Microbiology 23, 938-94I.

WARREN, J. C. \& Hatch, M. T. (1969). Survival of T3 coliphage in varied extracellular environments. I. Viability of the coliphage during storage and in aerosols. Applied Microbiology 17, 256-261.

Williams, R. C. \& Fraser, D. (1953). Morphology of the seven T-bacteriophages. Journal of Bacteriology $66,458-464$. 